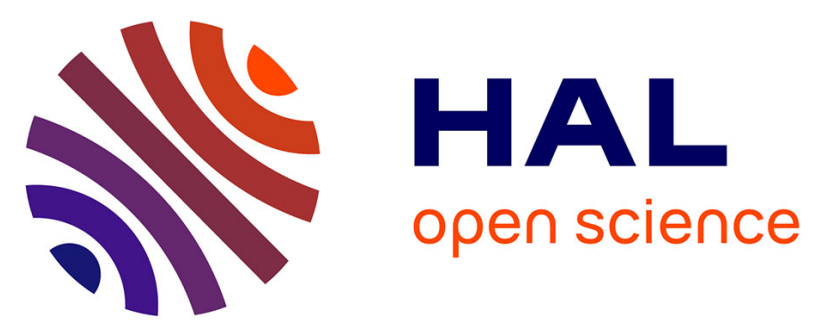

\title{
Visible and Near-Infrared Hyperspectral Imaging to Describe Properties of Conventionally and Organically Grown Carrots
}

Laima Česonienè, Gediminas Masaitis, Gintautas Mozgeris, Sébastien Gadal, Daiva Šileikienè, Rasa Karklelienè

\section{To cite this version:}

Laima Česonienè, Gediminas Masaitis, Gintautas Mozgeris, Sébastien Gadal, Daiva Šileikienè, et al.. Visible and Near-Infrared Hyperspectral Imaging to Describe Properties of Conventionally and Organically Grown Carrots. Journal of Elementology , 2019, 24 (2), pp.421 - 435. 10.5601/jelem.2018.23.4.1724 . hal-01996397

\section{HAL Id: hal-01996397 \\ https://hal-amu.archives-ouvertes.fr/hal-01996397}

Submitted on 28 Jan 2019

HAL is a multi-disciplinary open access archive for the deposit and dissemination of scientific research documents, whether they are published or not. The documents may come from teaching and research institutions in France or abroad, or from public or private research centers.
L'archive ouverte pluridisciplinaire HAL, est destinée au dépôt et à la diffusion de documents scientifiques de niveau recherche, publiés ou non, émanant des établissements d'enseignement et de recherche français ou étrangers, des laboratoires publics ou privés.

\section{(c)(1)}

Distributed under a Creative Commons Attribution| 4.0 International License 
Česonienė L., Masaitis G., Mozgeris G., Gadal S., Šileikienė D., Karklelienè R. 2019. Visible and near-infrared hyperspectral imaging to describe properties of conventionally and organically grown carrots.

J. Elem., 24(2): 421-435. DOI: 10.5601/jelem.2018.23.4.1724

\title{
VISIBLE AND NEAR-INFRARED HYPERSPECTRAL IMAGING TO DESCRIBE PROPERTIES OF CONVENTIONALLY AND ORGANICALLY GROWN CARROTS
}

\author{
Laima Česonienè ${ }^{1}$, Gediminas Masaitis ${ }^{2}$, Gintautas Mozgeris ${ }^{2}$, \\ Sébastien Gadal ${ }^{3}$, Daiva Śleikienè ${ }^{1}$, Rasa Karkleliené ${ }^{4}$ \\ ${ }^{1}$ Institute of Environment and Ecology \\ ${ }^{2}$ Institute of Forest Management and Wood Science \\ Aleksandras Stulginskis University, Kaunas, Lithuania \\ ${ }^{3}$ Aix Marseille Univ, Université Côte d'Azur, Avignon Université, \\ CNRS, ESPACE, UMR 7300, \\ Avignon, 13545 Aix-en-Provence, France \\ ${ }^{4}$ Institute of Horticulture \\ Lithuanian Research Centre for Agriculture and Forestry (LRCAF), \\ Babtai, Lithuania
}

\begin{abstract}
This paper discusses the potential of visible and near-infrared hyperspectral imaging to describe properties of conventionally and organically grown carrots. 140 samples of four Lithuanian carrot cultivars were scanned using a VNIR $400 \mathrm{H}$ hyperspectral camera, capable of covering the spectral range of 400-1000 nm with a sampling interval of $0.6 \mathrm{~nm}$. Half of the samples were grown under organic farming conditions and the remainder under conventional conditions. Chemical and electro-chemical properties, i.e. nitrate content, acidity, reduction potential and electrical conductivity, were determined for the carrot root samples using conventional methods of chemical investigations. The ability to separate organically and conventionally grown samples on the basis of spectral data was examined by applying estimations of Jeffries-Matusita distances and linear discriminant analysis. Opportunities to predict the chemical and electro-chemical properties of samples applying the partial least squares regression and the spectral data as predictors were also investigated. The overall classification accuracy of samples of organically and conventionally grown carrot cultivars when applying linear discriminant analysis was in the range of $94.4-100 \%$ and the Jeffries-Matusita distances were in the range of 1.98-2.00. There was good prediction potential using the partial least squares regression for electrical conductivity $\left(R^{2}=0.88\right)$ and reduction potential $\left(R^{2}=0.81\right)$, better than moderate for nitrate content $\left(R^{2}=0.77\right)$ and moderate for acidity $\left(R^{2}=0.68\right)$ using hyperspectral reflectance data of carrot captured under laboratory conditions. Both the separation ability and prediction potential were higher if taking into account the cultivar.
\end{abstract}

Keywords: carrots, chemical and electro-chemical properties, hyperspectral imaging, organic and conventional farming.

prof. dr Laima Cesoniene, prof. at Institute of Environment and Ecology, Aleksandras Stulginskis University, Studentu 11, Lt-53361 Akademia, Kaunas r., Lithuania, e-mail: laima.cesoniene@asu.lt 


\section{INTRODUCTION}

Numerous solutions used to monitor the food products aiming to ensure their quality are available: analytical methodologies such as potentiometric conductivity - electrophoresis and UV spectrometry (WU et al. 2010), mass spectra screen-printed biosensors, ion-pair extraction and gas chromatography, ion chromatography (ITO et al. 2010) and approaches based on holistic analysis (UlRICH et al. 2012). However, most of these methods require complex processing of samples, expensive chemical reagents and highly qualified personnel to implement operationally at a mass production level and are time consuming. The importance of rapid, cheap, easy to apply, non-destructive and objective techniques to evaluate the quality of organic products is also increasing along with the growing investment and research in the area of organic production (LAIRON 2010). Hyperspectral imaging is an emerging and promising approach for food quality and safety control (Pu et al. 2015). Hyperspectral imaging systems are instruments that capture images of an object in many narrow (nanometer level) contiguous spectral bands. Depending on their construction, they can sense the reflected or emitted electro-magnetic radiation in a range from the ultraviolet (from $200 \mathrm{~nm}$ ) to thermal (up to $15,000 \mathrm{~nm}$ ) waves (IM, JENSEN 2008). These instruments are constructed to collect hundreds of spectral bands for every pixel of an image, resulting in narrow waveband data which has a greater potential for precise identification, discrimination and classification of analyzed objects and their features (IM, JENSEN 2008).

There is interest in the use of hyperspectral imaging technology for non-destructive analysis in many application areas, including the food industry and agricultural production. These techniques have been used either in studies or operational applications such as quality evaluation of fruits and vegetables (Hu et al. 2016, ZHAO et al. 2010), estimation of physical and chemical characteristics of fruits and vegetables (ELMASRY et al. 2007, Zhao et al. 2009, Fernandes et al. 2011, RAJKumar al. 2012), or dealing with the properties related to processing and infestation of agricultural products (Williams et al. 2010, Do Trong et al. 2011, Huang et al. 2014, Nogales-Bueno et al. 2014).

Electro-magnetic waves, interacting with an object, are absorbed by, reflected from or transmitted into the material. Electronic transition and charge transfer processes largely determine the position of diagnostic absorption features in the VIS and NIR wavelengths of the spectra. The absorption features are determined by the particular physical and chemical structure of the material. Thus, the variables characterizing light absorption features can be directly related to the chemistry and structure of the sample (VAN DER MEER 2004). In spectroscopy, the partial least squares regression (PLSR) is a widely used method to develop predictive models for chemical constituents (which are optically active) of an investigated sample with spec- 
tral data, and is also very suitable for high-dimensional hyperspectral image data - when the number of samples is fewer than the number of investigated characteristics used as independent variables (Asner, Martin 2008).

Carrots (Daucus carota var. sativa) are chosen as an object of investigations in our study. There have been few studies on the implementation of spectral approaches for quality estimation of carrots. ScHulz et al. (2000) tested the possibility of estimating the amount of carotenoids according to NIR reflectance in carrot roots. BELIE et al. (2003) used non-destructive NIR reflectance measurements to predict a change in the sensory quality of carrots during heat treatment. QuiLiTzsch et al. (2005) studied various spectroscopic methods for non-destructive determination of various quality parameters (e.g. $\beta$-carotene and dry matter content) in carrots. ZuDE et al. (2007) tested the feasibility of hyperspectral imaging for monitoring the compounds determining carrot production quality (e.g. sugar and carotene contents) throughout the whole product storage time. FIRTHA (2009) investigated spectral changes of different cultivars and tissues of carrots stored under different conditions in regard to their moisture loss.

This paper aims to present the potential of hyperspectral imaging to evaluate the quality of organic products in a non-destructive way. We hypothesize that some properties of carrots, namely, nitrate $\left(\mathrm{NO}_{3}\right)$ content, acidity $(\mathrm{pH})$, reduction potential (ORP) and electrical conductivity $(\sigma)$, may be assessed using a hyperspectral imaging approach and deliver results compatible with the ones achieved by conventional methods of chemical investigations. Specific objectives of the study are (i) to investigate the potential of visible (VIS) and near-infrared (NIR) hyperspectral imaging as a possible solution to ensure a rapid, objective and non-destructive separation of organically and conventionally grown vegetable products, and (ii) to deal with some more specific methodological issues like a selection of the wavebands that best represent the spectral differences or the influence of different cultivars within the same species on the separation ability.

\section{MATERIAL AND METHODS}

\section{Sample description and measurements}

There were 140 carrot samples used for investigation (Table 1), aiming for at least 16 samples per cultivar and growing conditions. Four different carrot cultivars grown in Lithuania were represented in the study. Carrot samples of all cultivars were provided by the Institute of Horticulture, Lithuanian Research Centre for Agriculture and Forestry, and grown under conditions of organic (hereafter referred to as 'EKO') and conventional farms. All other growing conditions were considered to be uniform for all samples.

The hyperspectral scanning process was conducted using a Themis Vision Systems LLC hyperspectral camera VNIR400H. This device is 
Table 1

Number of samples investigated according to carrot cultivars and growing conditions

\begin{tabular}{|c|c|c|}
\hline \multirow{2}{*}{ Cultivar } & \multicolumn{2}{|c|}{ Number of samples } \\
\cline { 2 - 3 } & organic & conventional \\
\hline Garduolès & 16 & 20 \\
\hline Skalsa & 16 & 20 \\
\hline Svalia & 16 & 16 \\
\hline Satrija & 16 & 20 \\
\hline
\end{tabular}

equipped with a very sensitive spectrometer, capable of covering the spectral range of 400-1000 nm with a sampling interval of $0.6 \mathrm{~nm}$ and producing 955 spectral bands. The spatial data of scanned samples were recorded in a CCD array in $1392 \times 1000$ pixel resolution, with the pixel size of $6.45 \mu \mathrm{m} \times 6.45 \mu \mathrm{m}$. The camera's field of view was $30^{\circ}$. The camera was mounted on a copy stand and positioned so that the lens was fixed at $40 \mathrm{~cm}$ above a sample at the nadir position. Two 100-W halogen lamps were employed to provide stable electro-magnetic radiation in the $400-1000 \mathrm{~nm}$ range. The lamps were fixed symmetrically at both sides of the camera lens and illuminated the sample so that their light beams intersected each other above the sample.

The spectral curves derived from every pixel of each sample image were averaged to construct a unique spectral curve of the whole image. Finally, four reflectance curves were derived from the four sample images and then averaged to construct a single reflectance curve for each sample. In total, 140 reflectance curves were constructed. In a spreadsheet, each reflectance curve was treated as a series of numbers (reflectance coefficients) in 955 wavebands in 400-1000 nm. These series of numbers were used for statistical analyses.

Scanned samples were immediately submitted to laboratory measurements of $\mathrm{NO}_{3}, \mathrm{pH}, \mathrm{ORP}$ and $\sigma$. The concentration of $\mathrm{NO}_{3}$-nitrogen in carrots was determined by extraction with an aluminum sulfate solution and subsequent determination by an ion-selective electrode, as described in the Handbook of Methods for Plant Analysis (Miller 1998). Procedures defined in the Lithuanian National standard LST EN 1132:1994 were used to determine $\mathrm{pH}$. The $\sigma$ was measured using a WTW Inolab apparatus with calomel electrodes. The redox potential (OPR) in relation to the standard hydrogen electrode $\left(\mathrm{Eh}^{\prime}, \mathrm{mV}\right)$ was measured using a $781 \mathrm{pH} /$ Ion Meter apparatus with a special platinum electrode.

\section{Statistical analyses}

The distribution of the spectral responses at every spectral band and the distribution of data of chemical measurements were tested for normality us- 
ing the Shapiro-Wilk test $(\alpha=0.05)$. The homogeneity of the variance was checked using the Levene's test $(\alpha=0.05)$.

Student's $t$-test was applied to determine whether the differences in the measured $\mathrm{NO}_{3}, \mathrm{pH}, \mathrm{ORP}$ and $\sigma$ between conventionally and organically grown carrots were statistically significant. The null hypothesis $\mathrm{H}_{0}: \mu_{\text {conventional }}=\mu_{\text {organic }}$ was compared to the alternative hypothesis $\mathrm{H}_{1}: \mu_{\text {conventional }} \neq \mu_{\text {organic }}$, where $\mu$ was the mean value of $\mathrm{NO}_{3}, \mathrm{pH}, \mathrm{ORP}$ and $\sigma$ of the farming methods compared. The hypothesis test was carried out using two sample $t$-tests for all varieties $(\alpha=0.05)$.

Principal component analysis (PCA) was employed to reduce the dimensionality and redundancy inherent in hyperspectral data. The non-linear iterative partial least squares algorithm was employed in calculations (WoLD et al. 1987). In this study, PCA was used to compute the contribution of the reflectance originating from each wavelength to the principal components (PCs). The number of PCs used in the classification was determined by choosing enough eigenvectors to account for $99 \%$ of the variance in the original data.

The spectral separability between conventionally and organically grown cultivars, at the cultivar level and at the species level, was estimated using Jeffries-Matusita (JM) distances. Linear discriminant analysis (LDA) was applied for classification of conventionally and organically grown carrots. The PLSR was used for prediction of $\mathrm{NO}_{3}, \mathrm{pH}, \mathrm{ORP}$ and $\sigma$ independently using the wavelength reflectance values as the predictors. The leave-one-out cross validation was performed to check the fit and the predictive ability of the models. All four models were also validated using external data sets that were created by randomly selecting $30 \%$ of samples from initial data sets. For the best predicted attributes (coefficient of determination $>0.5$ ) the wavebands which were most sensitive to detection of those attributes were identified by using regression coefficients resulting from the PLSR models.

\section{RESULTS}

The reflectance data for every spectral band as well as the values of chemical and electro-chemical parameters were homoscedastic and normally distributed $(p>\alpha)$. The statistical characteristics of laboratory measured $\mathrm{NO}_{3}, \mathrm{pH}, \mathrm{ORP}$ and $\sigma$ are presented in Table 2.

Within the same cultivar, tested chemical and electro-chemical properties of conventionally and organically grown carrots differed significantly in some cases only (Table 3). The $\sigma$ was significantly different in all cases of tested cultivars, the $\mathrm{NO}_{3}$ concentration and ORP were significantly different for only one cultivar, and $\mathrm{pH}$ was significantly different in two cultivars.

The PCA indicated that if the first six PCs were retained then $>99 \%$ of the variation in the initial spectral data was represented. Thus, the six 
Table 2

Measured chemical and electro-chemical attributes of carrot samples

\begin{tabular}{|c|c|c|c|c|c|}
\hline \multirow{2}{*}{ Attribute } & \multirow{2}{*}{ Statistic } & \multicolumn{4}{|c|}{ Cultivar } \\
\hline & & Garduolès & Šatrija & Skalsa & Svalia \\
\hline \multicolumn{6}{|c|}{ Conventionally grown } \\
\hline \multirow{4}{*}{$\mathrm{NO}_{3}\left(\mathrm{mg} \mathrm{l}^{-1}\right)$} & mean & 48.90 & 273.3 & 13.30 & 123.6 \\
\hline & SD & 43.95 & 423.6 & 1.750 & 102.6 \\
\hline & $\min$ & 26.50 & 38.00 & 10.00 & 44.00 \\
\hline & $\max$ & 170.0 & 1100 & 16.50 & 305.0 \\
\hline \multirow{4}{*}{$\mathrm{pH}$} & mean & 6.340 & 6.360 & 6.340 & 6.520 \\
\hline & SD & 0.090 & 0.100 & 0.120 & 0.120 \\
\hline & $\min$ & 6.160 & 6.190 & 6.130 & 6.310 \\
\hline & $\max$ & 6.470 & 6.540 & 6.470 & 6.660 \\
\hline \multirow{4}{*}{ ORP (mV) } & mean & 234.6 & 249.2 & 171.7 & 160.9 \\
\hline & SD & 52.87 & 20.67 & 26.77 & 69.19 \\
\hline & $\min$ & 172.0 & 232.0 & 146.0 & 109.0 \\
\hline & $\max$ & 291.0 & 302.0 & 219.0 & 273.0 \\
\hline \multirow{4}{*}{$\sigma\left(\mathrm{mS} \mathrm{cm} \mathrm{cm}^{-1}\right)$} & mean & 5.270 & 8.300 & 6.510 & 8.870 \\
\hline & SD & 0.920 & 1.610 & 1.220 & 0.660 \\
\hline & $\min$ & 3.730 & 5.290 & 4.620 & 7.990 \\
\hline & $\max$ & 7.190 & 10.05 & 8.150 & 9.790 \\
\hline \multicolumn{2}{|c|}{ Number of samples } & 20 & 20 & 20 & 16 \\
\hline \multicolumn{6}{|c|}{ Organically grown } \\
\hline \multirow{4}{*}{$\mathrm{NO}_{3}\left(\mathrm{mg} \mathrm{l}^{-1}\right)$} & mean & 62.25 & 94.81 & 71.56 & 45.56 \\
\hline & SD & 47.66 & 99.61 & 63.17 & 12.65 \\
\hline & $\min$ & 28.50 & 36.50 & 13.50 & 23.50 \\
\hline & $\max$ & 145.0 & 275.0 & 165.0 & 65.00 \\
\hline \multirow{4}{*}{$\mathrm{pH}$} & mean & 6.270 & 6.350 & 6.380 & 6.300 \\
\hline & $\mathrm{SD}$ & 0.040 & 0.090 & 0.060 & 0.100 \\
\hline & $\min$ & 6.210 & 6.220 & 6.290 & 6.160 \\
\hline & $\max$ & 6.310 & 6.470 & 6.470 & 6.430 \\
\hline \multirow{4}{*}{ ORP (mV) } & mean & 210.8 & 146.4 & 169.0 & 142.1 \\
\hline & $\mathrm{SD}$ & 51.60 & 12.16 & 17.37 & 32.04 \\
\hline & $\min$ & 156.0 & 128.0 & 152.0 & 120.0 \\
\hline & $\max$ & 307.0 & 163.0 & 200.0 & 209.0 \\
\hline \multirow{4}{*}{$\sigma\left(\mathrm{mS} \mathrm{cm} \mathrm{cm}^{-1}\right)$} & mean & 3.820 & 4.240 & 5.320 & 3.930 \\
\hline & SD & 1.330 & 0.890 & 0.930 & 0.600 \\
\hline & $\min$ & 2.310 & 2.820 & 3.890 & 3.240 \\
\hline & $\max$ & 5.790 & 4.970 & 6.500 & 4.830 \\
\hline \multicolumn{2}{|c|}{ Number of samples } & 16 & 16 & 16 & 16 \\
\hline
\end{tabular}


Differences between measured mean values of $\mathrm{NO}_{3}, \mathrm{pH}, \mathrm{ORP}$ and $\sigma$ of organically and conventionally grown carrots

\begin{tabular}{|l|l|c|c|c|c|}
\hline \multicolumn{1}{|c|}{ Cultivar } & \multicolumn{1}{c|}{ Attribute } & $\begin{array}{c}\mathrm{NO}_{3} \\
\left(\mathrm{mg} \mathrm{l}^{-1}\right)\end{array}$ & $\mathrm{pH}$ & $\begin{array}{c}\mathrm{ORP} \\
(\mathrm{mV})\end{array}$ & $\begin{array}{c}\boldsymbol{\sigma} \\
\left(\mathbf{m S ~ c m}^{-1}\right)\end{array}$ \\
\hline $\begin{array}{l}\text { Garduolès / } \\
\text { / Garduolès EKO }\end{array}$ & differences (\%) & -27.30 & 1.150 & 10.17 & 27.47 \\
\cline { 2 - 6 } & significance ( $p$-value) & 0.550 & $\mathbf{0 . 0 5 0}$ & 0.350 & $\mathbf{0 . 0 1 0}$ \\
\hline \multirow{2}{*}{ Šatrija / Šatrija EKO } & differences (\%) & 65.30 & 0.180 & 41.26 & 48.89 \\
\cline { 2 - 6 } & significance ( $p$-value) & 0.260 & 0.810 & $\mathbf{1 . 2 6 E - 0 9}$ & $\mathbf{9 . 0 4 E - 0 6}$ \\
\hline \multirow{2}{*}{ Skalsa / Skalsa EKO } & differences (\%) & -438.06 & -0.510 & 1.570 & 18.28 \\
\cline { 2 - 6 } & significance ( $p$-value) & $\mathbf{0 . 0 3 0}$ & 0.480 & 0.810 & $\mathbf{0 . 0 4 0}$ \\
\hline \multirow{2}{*}{ Svalia / Svalia EKO } & differences (\%) & 63.14 & 3.370 & 11.660 & -125.6 \\
\cline { 2 - 7 } & significance ( $p$-value) & 0.070 & $\mathbf{1 . 4 1 E - 0 3}$ & 0.500 & $\mathbf{2 . 9 0 E - 1 0}$ \\
\hline
\end{tabular}

Significant differences $(p<0.05)$ are marked in bold.

wavebands with the highest absolute values of component loadings to PC1-PC6 were selected as optimal ones to discriminate the carrot cultivars and farming method. The green, yellow, red and NIR portions of the spectra were the most important in sample discrimination (Table 4).

Poor spectral separation ability could be expected based on measured JM distances between conventionally and organically grown carrot samples (JM distance was 0.9032 , i.e. $<1$ ) when the cultivar was not assumed (Table 5). However, if the spectral properties of the same cultivar were compared, the JM distances suggested excellent separation ability (JM distance approached or equaled 2).

When the carrot cultivar was taken into account, perfect classification accuracy using the LDA was achieved for the cultivars Skalsa, Svalia and Šatrija $(\hat{\kappa}=1.0)$, and almost perfect for cv. Garduolès $(\hat{\kappa}=0.89)-$ Table 6 . These results were fully compatible with the measurements of JM distances. There was only moderate classification accuracy when all investigated sam-

Table 4

Variance explained by principal components (\%) and wavelengths (nm) most sensitive to carrot cultivar and farming method separation

\begin{tabular}{|c|c|c|}
\hline Principal component (PC) & Variance explained & Most informative wavelength \\
\hline PC1 & 57.90 & 878.3 \\
\hline PC2 & 33.40 & 504.1 \\
\hline PC3 & 4.200 & 678.6 \\
\hline PC4 & 1.700 & 722.1 \\
\hline PC5 & 1.600 & 573.9 \\
\hline PC6 & 0.800 & 534.5 \\
\hline
\end{tabular}


Spectral separability of conventionally and organically grown carrot samples according to Jeffries-Matusita (JM) distances

\begin{tabular}{|c|c|}
\hline Cultivar & JM distance \\
\hline Garduolès & 1.989 \\
\hline Šatrija & 1.979 \\
\hline Skalsa & 1.986 \\
\hline Svalia & 2.000 \\
\hline All & 0.903 \\
\hline
\end{tabular}

The accuracy of sample classification according to farming methods

\begin{tabular}{|c|c|c|c|c|}
\hline Cultivar & Farming method & $\begin{array}{c}\text { Classified } \\
\text { as conventional }\end{array}$ & $\begin{array}{l}\text { Classified } \\
\text { as organic }\end{array}$ & Producer's accuracy \\
\hline \multirow{2}{*}{ Garduolès } & conventional & 18 & 2 & $90 \%$ \\
\hline & EKO & 0 & 16 & $100 \%$ \\
\hline \multicolumn{2}{|c|}{ User's accuracy } & $100 \%$ & $88.9 \%$ & \\
\hline \multicolumn{4}{|c|}{ Overall classification accuracy } & $94.4 \%$ \\
\hline \multicolumn{4}{|c|}{$\hat{\kappa}$} & 0.89 \\
\hline \multirow{2}{*}{ Skalsa } & conventional & 20 & 0 & $100 \%$ \\
\hline & organic & 0 & 16 & $100 \%$ \\
\hline \multicolumn{2}{|c|}{ User's accuracy } & $100 \%$ & $100 \%$ & \\
\hline \multicolumn{4}{|c|}{ Overall classification accuracy } & $100 \%$ \\
\hline \multicolumn{4}{|c|}{$\hat{\kappa}$} & 1.00 \\
\hline \multirow{2}{*}{ Svalia } & conventional & 16 & 0 & $100 \%$ \\
\hline & organic & 0 & 16 & $100 \%$ \\
\hline \multicolumn{2}{|c|}{ User's accuracy } & $100 \%$ & $100 \%$ & \\
\hline \multicolumn{4}{|c|}{ Overall classification accuracy } & $100 \%$ \\
\hline \multicolumn{4}{|c|}{$\hat{\kappa}$} & 1.00 \\
\hline \multirow{2}{*}{ Šatrija } & conventional & 20 & 0 & $100 \%$ \\
\hline & organic & 0 & 16 & $100 \%$ \\
\hline \multicolumn{2}{|c|}{ User's accuracy } & $100 \%$ & $100 \%$ & \\
\hline \multicolumn{4}{|c|}{ Overall classification accuracy } & $100 \%$ \\
\hline \multicolumn{4}{|c|}{$\hat{\kappa}$} & 1.00 \\
\hline \multirow{2}{*}{ All } & conventional & 54 & 22 & $71.0 \%$ \\
\hline & organic & 20 & 44 & $68.8 \%$ \\
\hline User's accuracy & & $73.0 \%$ & $66.7 \%$ & \\
\hline \multicolumn{4}{|c|}{ Overall classification accuracy } & $70.0 \%$ \\
\hline \multicolumn{4}{|c|}{$\hat{\kappa}$} & 0.40 \\
\hline
\end{tabular}


ples, regardless of a cultivar, were classified into two classes, i.e. conventionally and organically grown ones $(\hat{\kappa}=0.40)$.

There was good potential prediction performance for $\sigma\left(R^{2}=0.88\right)$ and ORP $\left(R^{2}=0.81\right)$, better than moderate for $\mathrm{NO}_{3}\left(R^{2}=0.77\right)$ and moderate for $\mathrm{pH}\left(R^{2}=0.68\right)$ for all samples used, i.e. regardless of a cultivar or a farming method (Table 7, Figure 1). The performance of prediction varied depending

Table 7

Parameters of PLSR models to predict the $\mathrm{NO}_{3}, \mathrm{pH}$, ORP and $\sigma$

\begin{tabular}{|c|c|c|c|c|}
\hline Cultivar & Attribute & $\begin{array}{c}\text { Leave-one-out } \\
\text { cross validated } \\
R^{2}\end{array}$ & $\begin{array}{c}\text { Root mean square } \\
\text { errors } \\
\text { of prediction }\end{array}$ & $\begin{array}{c}\text { Mean absolute } \\
\text { percentage error } \\
(\%)\end{array}$ \\
\hline \multirow{4}{*}{$\begin{array}{l}\text { Garduolès, } \\
36 \text { samples }\end{array}$} & $\mathrm{NO}_{3}\left(\mathrm{mg} \mathrm{l}^{-1}\right)$ & 0.85 & 3.34 & 8.12 \\
\hline & $\mathrm{pH}$ & 0.83 & 0.02 & 0.35 \\
\hline & ORP $(\mathrm{mV})$ & 0.62 & 33.61 & 12.92 \\
\hline & $\sigma\left(\mathrm{mS} \mathrm{cm} \mathrm{cm}^{-1}\right)$ & 0.79 & 0.63 & 9.92 \\
\hline \multirow{4}{*}{$\begin{array}{l}\text { Šatrija, } \\
36 \text { samples }\end{array}$} & $\mathrm{NO}_{3}\left(\mathrm{mg} \mathrm{l}^{-1}\right)$ & 0.65 & 12.34 & 17.63 \\
\hline & $\mathrm{pH}$ & 0.39 & 0.05 & 0.73 \\
\hline & ORP $(\mathrm{mV})$ & 0.93 & 15.14 & 6.6 \\
\hline & $\sigma\left(\mathrm{mS} \mathrm{cm}^{-1}\right)$ & 0.89 & 0.64 & 11.2 \\
\hline \multirow{4}{*}{$\begin{array}{l}\text { Skalsa, } \\
36 \text { samples }\end{array}$} & $\mathrm{NO}_{3}\left(\mathrm{mg} \mathrm{l}^{-1}\right)$ & 0.97 & 0.28 & 1.88 \\
\hline & $\mathrm{pH}$ & 0.84 & 0.05 & 0.63 \\
\hline & ORP $(\mathrm{mV})$ & 0.9 & 8.15 & 3.98 \\
\hline & $\sigma\left(\mathrm{mS} \mathrm{cm}^{-1}\right)$ & 0.94 & 0.28 & 3.91 \\
\hline \multirow{4}{*}{$\begin{array}{c}\text { Svalia, } \\
36 \text { samples }\end{array}$} & $\mathrm{NO}_{3}\left(\mathrm{mg} \mathrm{l}^{-1}\right)$ & 0.99 & 0.34 & 0.53 \\
\hline & $\mathrm{pH}$ & 0.94 & 0.03 & 0.38 \\
\hline & ORP $(\mathrm{mV})$ & 0.87 & 20.22 & 13.36 \\
\hline & $\sigma\left(\mathrm{mS} \mathrm{cm}^{-1}\right)$ & 0.98 & 0.18 & 3.22 \\
\hline \multirow{4}{*}{$\begin{array}{c}\text { All conventionally } \\
\text { grown, } \\
76 \text { samples }\end{array}$} & $\mathrm{NO}_{3}\left(\mathrm{mg} \mathrm{l}^{-1}\right)$ & 0.65 & 13.91 & 45.7 \\
\hline & $\mathrm{pH}$ & 0.41 & 0.1 & 1.33 \\
\hline & ORP $(\mathrm{mV})$ & 0.81 & 26.44 & 12.35 \\
\hline & $\sigma\left(\mathrm{mS} \mathrm{cm} \mathrm{cm}^{-1}\right)$ & 0.85 & 0.75 & 10.16 \\
\hline \multirow{4}{*}{$\begin{array}{l}\text { All organically } \\
\text { grown, } \\
64 \text { samples }\end{array}$} & $\mathrm{NO}_{3}\left(\mathrm{mg} \mathrm{l}^{-1}\right)$ & 0.93 & 4.46 & 14.34 \\
\hline & $\mathrm{pH}$ & 0.87 & 0.03 & 0.37 \\
\hline & ORP $(\mathrm{mV})$ & 0.73 & 11.6 & 6.38 \\
\hline & $\sigma\left(\mathrm{mS} \mathrm{cm}^{-1}\right)$ & 0.9 & 64 & 10.93 \\
\hline \multirow{4}{*}{ All, 140 samples } & $\mathrm{NO}_{3}\left(\mathrm{mg} \mathrm{l}^{-1}\right)$ & 0.77 & 5.95 & 16.7 \\
\hline & $\mathrm{pH}$ & 0.68 & 0.06 & 0.9 \\
\hline & ORP $(\mathrm{mV})$ & 0.81 & 23.34 & 10.2 \\
\hline & $\sigma\left(\mathrm{mS} \mathrm{cm} \mathrm{cm}^{-1}\right)$ & 0.88 & 0.66 & 9.9 \\
\hline
\end{tabular}



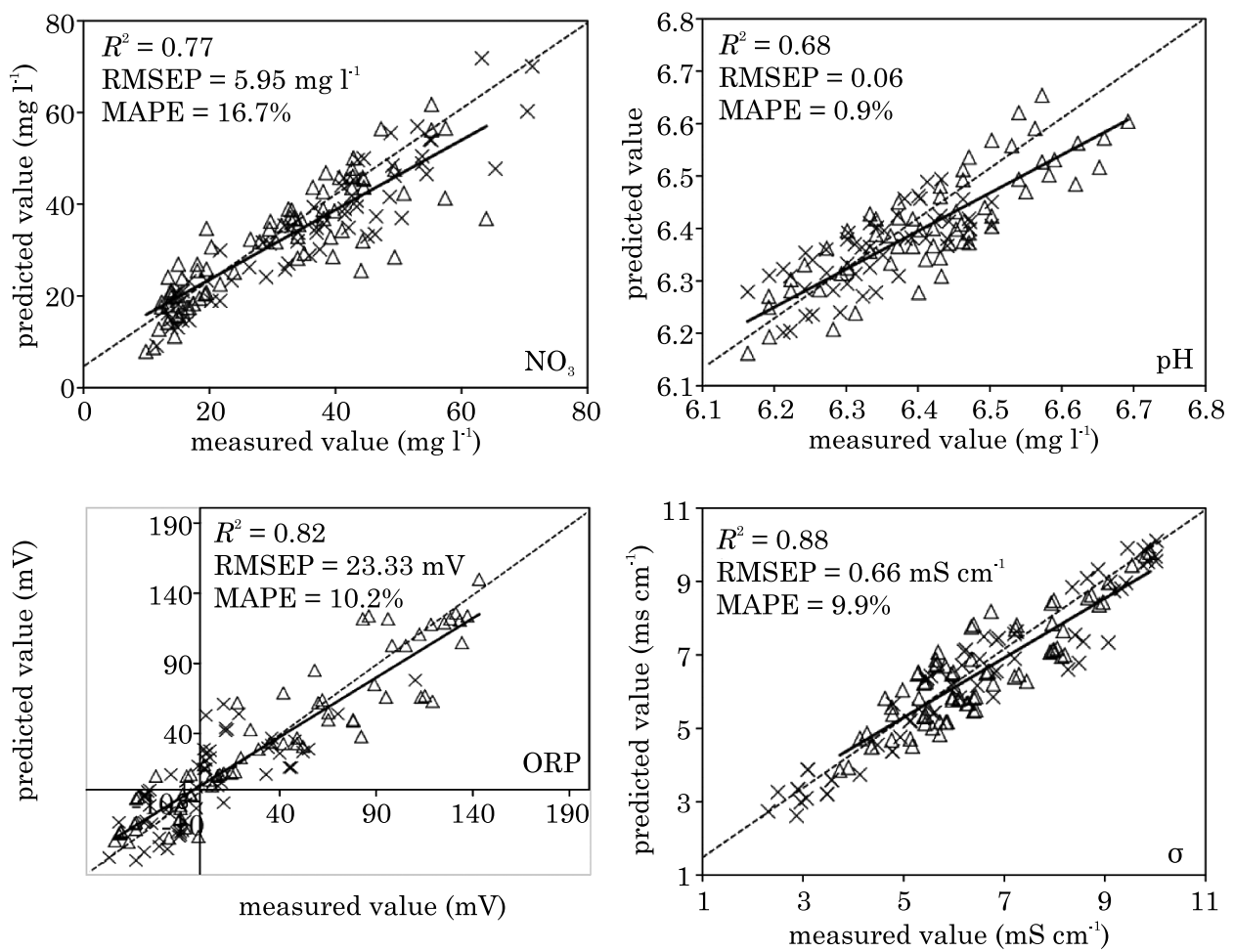

Fig. 1. Measured and predicted values of $\mathrm{pH}, \mathrm{ORP}, \sigma$ and $\mathrm{NO}_{3}$, including the full spectral range of all investigated samples (residuals referring to conventionally grown samples are marked ' $\Delta$ ', organically ' $\mathrm{X}$ ')

on a cultivar and a farming method. However, the small number of samples should be kept in mind.

The best prediction of $\mathrm{NO}_{3}, \mathrm{pH}$ and $\sigma$ was achieved for cv. Svalia, and of ORP for cv. Satrija. The aforementioned attributes were better predicted for organically grown compared to conventionally grown samples (Table 7) - the prediction $R^{2}$ was improved for all chemical and electro-chemical properties if only organically grown samples were considered.

The wavebands most tightly related to $\mathrm{pH}, \mathrm{ORP}, \sigma$ and $\mathrm{NO}_{3}$ concentration are summarized in Table 8. The majority of most informative wavelengths for $\mathrm{NO}_{3}$ concentration were located in NIR; for $\mathrm{pH}$ in violet, green and red; for ORP in violet, blue and green; and for $\sigma$ in green-red portions of the spectra (Table 8). 
The most sensitive wavelengths selected according to PLSR coefficients (ordered in ascending order)

\begin{tabular}{|c|c|c|}
\hline Cultivar & Attribute & Most sensitive wavelengths (nm) \\
\hline \multirow{4}{*}{ Garduolès, 36 samples } & $\mathrm{NO}_{3}\left(\mathrm{mg} \mathrm{l}^{-1}\right)$ & $471.8 ; 502.8 ; 698.5 ; 777.1 ; 901.4 ; 921.3$ \\
\hline & $\mathrm{pH}$ & $413.1 ; 434.1 ; 554.1 ; 770.0 ; 905.9 ; 962.3$ \\
\hline & $\mathrm{ORP}(\mathrm{mV})$ & $423.9 ; 437.1 ; 490.0 ; 540.6 ; 589.1 ; 783.0$ \\
\hline & $\sigma\left(\mathrm{mS} \mathrm{cm}^{-1}\right)$ & $414.8 ; 454.7 ; 485.2 ; 652.4 ; 732.9 ; 946.3$ \\
\hline \multirow{4}{*}{ Šatrija, 36 samples } & $\mathrm{NO}_{3}\left(\mathrm{mg} \mathrm{l}^{-1}\right)$ & $451.7 ; 478.5 ; 691.4 ; 819.3 ; 823.2 ; 978.9$ \\
\hline & $\mathrm{pH}$ & $438.9 ; 440.1 ; 537.6 ; 686.3 ; 973.2 ; 978.9$ \\
\hline & $\mathrm{ORP}(\mathrm{mV})$ & $400.6 ; 450.5 ; 533.3 ; 546.1 ; 590.4 ; 729.1$ \\
\hline & $\sigma\left(\mathrm{mS} \mathrm{cm}^{-1}\right)$ & $451.7 ; 474.8 ; 544.3 ; 636.4 ; 675.4 ; 973.8$ \\
\hline \multirow{4}{*}{ Skalsa, 36 samples } & $\mathrm{NO}_{3}\left(\mathrm{mg} \mathrm{l}^{-1}\right)$ & $438.9 ; 560.3 ; 688.2 ; 764.8 ; 862.3 ; 986.0$ \\
\hline & $\mathrm{pH}$ & $427.3 ; 457.2 ; 512.0 ; 692.1 ; 918.7 ; 985.3$ \\
\hline & ORP $(\mathrm{mV})$ & $422.2 ; 434.7 ; 469.9 ; 564.6 ; 674.2 ; 720.1$ \\
\hline & $\sigma\left(\mathrm{mS} \mathrm{cm}^{-1}\right)$ & $442.5 ; 484.0 ; 540.0 ; 653.7 ; 679.9 ; 961.6$ \\
\hline \multirow{4}{*}{ Svalia, 36 samples } & $\mathrm{NO}_{3}\left(\mathrm{mg} \mathrm{l}^{-1}\right)$ & $402.3 ; 559.0 ; 681.8 ; 780.4 ; 885.4 ; 975.1$ \\
\hline & $\mathrm{pH}$ & $415.4 ; 439.5 ; 519.3 ; 693.3 ; 930.2 ; 966.8$ \\
\hline & $\mathrm{ORP}(\mathrm{mV})$ & $400.6 ; 425.6 ; 457.8 ; 544.9 ; 593.6 ; 726.5$ \\
\hline & $\sigma\left(\mathrm{mS} \mathrm{cm}^{-1}\right)$ & $404.6 ; 483.3 ; 543.0 ; 653.7 ; 684.4 ; 967.4$ \\
\hline \multirow{4}{*}{$\begin{array}{l}\text { All conventionally grown, } \\
76 \text { samples }\end{array}$} & $\mathrm{NO}_{3}\left(\mathrm{mg} \mathrm{l}^{-1}\right)$ & $454.1 ; 512.6 ; 694.6 ; 788.8 ; 881.5 ; 960.4$ \\
\hline & $\mathrm{pH}$ & $414.8 ; 442.5 ; 538.2 ; 680.6 ; 958.4 ; 969.3$ \\
\hline & $\mathrm{ORP}(\mathrm{mV})$ & $402.9 ; 414.3 ; 441.9 ; 529.6 ; 632.6 ; 724.6$ \\
\hline & $\sigma\left(\mathrm{mS} \mathrm{cm}^{-1}\right)$ & $476.6 ; 530.9 ; 535.1 ; 656.3 ; 678.6 ; 946.9$ \\
\hline \multirow{4}{*}{$\begin{array}{l}\text { All organically grown, } \\
64 \text { samples }\end{array}$} & $\mathrm{NO}_{3}\left(\mathrm{mg} \mathrm{l}^{-1}\right)$ & $437.1 ; 542.4 ; 679.9 ; 758.4 ; 868.1 ; 980.9$ \\
\hline & $\mathrm{pH}$ & $433.6 ; 449.2 ; 547.9 ; 724.0 ; 970.0 ; 977.0$ \\
\hline & $\mathrm{ORP}(\mathrm{mV})$ & $406.9 ; 413.1 ; 490.0 ; 572.6 ; 579.5 ; 770.6$ \\
\hline & $\sigma\left(\mathrm{mS} \mathrm{cm}^{-1}\right)$ & $435.8 ; 482.7 ; 544.3 ; 676.7 ; 718.9 ; 962.9$ \\
\hline \multirow{4}{*}{ All, 140 samples } & $\mathrm{NO}_{3}\left(\mathrm{mg} \mathrm{l}^{-1}\right)$ & $508.9 ; 539.4 ; 697.2 ; 761.0 ; 887.3 ; 953.3$ \\
\hline & $\mathrm{pH}$ & $444.4 ; 475.4 ; 583.4 ; 739.9 ; 953.3 ; 971.9$ \\
\hline & ORP $(\mathrm{mV})$ & $401.2 ; 415.4 ; 509.5 ; 538.2 ; 612.8 ; 759.7$ \\
\hline & $\sigma\left(\mathrm{mS} \mathrm{cm} \mathrm{cm}^{-1}\right)$ & $448.6 ; 506.5 ; 565.2 ; 653.1 ; 713.8 ; 959.7$ \\
\hline
\end{tabular}

\section{DISCUSSION}

The benefits of hyperspectral imaging are better exploited when the method is used for online inspection of quality and safety of agricultural products (Wu, Sun 2013). However, the hyperspectral camera, image acqui- 
sition and processing approaches used in the current study were aimed to be applied in laboratory investigations. Therefore, the subsequent discussion focuses on the methodological issues of using hyperspectral imaging to assess properties of agricultural products, in this case, conventionally and organically grown carrots. Carrots are one of the most common vegetables consumed in Lithuania, with an increasing share of organically grown production. Carrot roots have been subject to spectral investigations; however, the focus has usually been the prediction of carotene and sugar content (Schulz et al. 2000, Quilitzsch et al. 2005, Zude et al. 2007). There has been little spectral research of carrots so far (BELIE et al. 2003, FiRTHA 2009).

Significant differences in $\sigma$ between organically and conventionally grown carrots (Table 2) suggest that different farming methods most strongly affected the $\sigma$ of roots, and factors influencing $\sigma$ were the most important to spectral reflectance properties of carrot roots. Changes occurring in cell walls, membranes and compositions of cell contents, also the type of biomaterial and condition of the structure of cells, can affect $\sigma$ (SAsson, Monselise 1977). The $\sigma$ is proportional to the total concentration of solutes in the nutrient solution (WINSOR, ADAMs 1987), thus changes in cell condition and structure can also affect the properties of spectral reflectance, especially in the NIR region of the spectrum (NicolAÏ et al. 2007). This was evident in our study too, as the wavelength most sensitive to a carrot cultivar and farming method separation was exactly in NIR region (878.34 nm) - Table 4.

There was only moderate potential to separate the samples into groups of conventionally and organically grown carrots using spectral data and LDA if a cultivar was not considered. This result, also supported by the JM distance measurement, suggests that there were greater differences within the compared features among the cultivars grown under the organic or conventional regime. All samples were provided from research fields of the Institute of Horticulture, and thus the growing conditions were comparable except for those predefined by the conventional and organic farming systems.

The investigated chemical and electro-chemical properties of the carrot cultivars did not generally differ significantly regarding a cultivation method (organic/conventional). Only o differed significantly between conventionally and organically grown carrots for all cultivars. Amounts of $\mathrm{NO}_{3}$ and ORP differed significantly only for one cultivar each (Garduolès and Šatrija, respectively), and $\mathrm{pH}$ significantly differed in two cases (Garduolès and Svalia). This suggests that differences due to the growing regime were most pronounced in the case of $\sigma$, as measured $\sigma$ was consistently higher in roots of conventionally compared to organically grown carrots.

The selection of only several optimal wavebands for calculation of JM distances was predetermined by the restrictions of the method itself. The JM distance measurement applied in our study is a parametric method based on covariance matrixes calculation. Calculation of the JM distance using all 955 bands was not possible because of the singularity problem 
of matrix inversion (the number of 16 spectral samples per carrot cultivar was insufficient for such a calculation). Many studies have shown that a smaller set of spectral bands can generate more accurate results than the whole set (DEBACKER et al. 2005, VAIPHASA ET al 2005). Many authors have reported JM distance as an appropriate separability measure. In our study, the assumptions based on JM distances were fully confirmed by the LDA results.

The $\mathrm{NO}_{3}, \mathrm{ORP}$ and $\sigma$ in carrot roots were found to be predictable based on the data from the VIS-NIR hyperspectral reflectance measurements. There have been some more successful studies dealing with the prediction of the $\mathrm{NO}_{3}$ concentration in vegetables according to their spectral data; however, to our best knowledge, none dealt with carrot roots. Nevertheless the most successful studies in $\mathrm{NO}_{3}$ estimation in vegetables have employed either a broader range NIR spectroscopy, or UV spectroscopy (NAM et al. 2008).

In the present study, there were poor results of the prediction of $\mathrm{pH}$ and ORP in carrots roots according to their hyperspectral reflectance measurements in the 400-1000 $\mathrm{nm}$ range. There have been some successful studies dealing with the prediction of $\mathrm{pH}$ in fruits or berries according to their spectral measurements (LiU, Ying 2005, Gómez et al. 2006, ElmasRY et al. 2007, Shao et al. 2007, Moghimi et al. 2010), however, none of them dealt with the prediction of $\mathrm{pH}$ of roots. The best prediction results in these previous studies were achieved employing substantially more samples and broader spectral ranges - up to $2500 \mathrm{~nm}$ in some studies.

\section{CONCLUSION}

Spectral data captured using VIS and NIR hyperspectral imaging had a high classification potential of conventionally and organically grown carrots when a cultivar was taken into account. Overall classification accuracy of the four Lithuanian carrot cultivars, conventionally and organically grown, using LDA was in the range of $94.4-100 \%$ and the JM distances were in the range of 1.98-2.00. However, hyperspectral reflectance data resulted in moderate separation ability of the samples of conventionally and organically grown carrots (with an overall classification accuracy of $70 \%$ and $\mathrm{JM}$ distance of 0.90 ) when a cultivar was not taken into account. The methodology developed allowed good prediction potential using PLSR for $\sigma\left(R^{2}=0.88\right.$; MAPE $=9.9 \%)$ and ORP $\left(R^{2}=0.81\right.$; MAPE $\left.=10.2 \%\right)$, better than moderate for $\mathrm{NO}_{3}$ content $\left(R^{2}=0.77 ; \mathrm{MAPE}=16.7 \%\right)$ and moderate for $\mathrm{pH}\left(R^{2}=0.68\right.$; MAPE $=0.9 \%$ ) - hence they can be employed as predictors with hyperspectral reflectance data of carrots captured under laboratory conditions. The prediction potential improved when considering a cultivar or only organically grown samples. 


\section{REFERENCES}

Asner G., Martin R. 2008. Spectral and chemical analysis of tropical forests: Scaling from leaf to canopy levels. Remote Sensing Environ., 112: 3958-3970.

Belie N.D., Pedersen D.K., Martens M., Bro R., Munck L., Baerdemaeker J.D.2003. The use of visible and near-infrared reflectance measurements to assess sensory changes in carrot texture and sweetness during heat treatment. Biosyst. Engin., 85: 213-225.

DeBacker S., Kempeneers P., Debruyn W., Scheunders P. 2005. Band selection for hyperspectral remote sensing. IEEE Geosci. Remote SL., 2: 319-323.

Do Trong N.N., Tsuta M., Nicolaï B.M., De Baerdemaeker J., Saeys W. 2011. Prediction of optimal cooking time for boiled potatoes by hyperspectral imaging. J. Food Engin., 105: 617-624.

ElMasry G., Wang N., ElSayed A., Ngadi M. 2007. Hyperspectral imaging for nondestructive determination of some quality attributes for strawberry. J. Food Engin., 81: 98-107.

Fernandes A.M., Oliveira P., Moura J.P., Oliveira A.A., Falco V., Correia M.J., Melo-Pinto P. 2011. Determination of anthocyanin concentration in whole grape skins using hyperspectral imaging and adaptive boosting neural networks. J. Food Engin. 105: 216-226.

FirTha F. 2009. Detecting moisture loss of carrot samples during storage by hyperspectral imaging system. Acta Aliment., 38: 55-66.

Gómez A.H., He Y., Pereira A.G. 2006. Non-destructive measurement of acidity, soluble solids and firmness of Satsuma mandarin using Vis/NIR-spectroscopy techniques. J. Food Engin., 77: 313-319.

Hu M.-H., Dong Q.-L., LiU B.-L. 2016. Modelling postharvest quality of blueberry affected by biological variability using image and spectral data. J. Sci. Food Agric., 96: 3365-3373.

Huang M., Wang Q., Zhang M., Zhu Q. 2014. Prediction of color and moisture content for vegetable soybean during drying using hyperspectral imaging technology. J. Food Engin., 128: 24-30.

Iм J., Jensen J.R. 2008. Hyperspectrai remote sensing of vegetation. Geography Compass, 2: 1943-1961.

Ito H., Kanda S., Matsuura H., Shiraishi N., Sakai K., Sasao A. 2010. Measurement of nitrate concentration distribution in vegetables by Near-Infrared hyperspectral imaging. Environ. Control Biol., 48: 37-49.

Lairon D. 2010. Nutritional quality and safety of organic food. A review. Agron. Sustain. Dev., 30: 33-41.

LIU Y., YING Y. 2005. Use of FT-NIR spectrometry in non-invasive measurements of internal quality of 'Fuji'apples. Postharvest Biol. Tech., 37: 65-71.

Moghimi A., Aghkhani M.H., Sazgarnia A., Sarmad M. 2010. Vis/NIR spectroscopy and chemometrics for the prediction of soluble solids content and acidity $(\mathrm{pH})$ of kiwifruit. Biosyst. Engin., 106: 295-302.

MiLLER R.O. 1998. Extractable nitrate in plant tissue: ion-selective electrode method. In: Handbook of methods for plant analysis. KaLRA Y.P. (Ed.). CRC Press Taylor \& Francis Group, 85-88.

Nam P., Alejandra B., Frederic H., Didier B., Olivier S., Pauss A. 2008. A new quantitative and low-cost determination method of nitrate in vegetables, based on deconvolution of UV spectra. Talanta, 76: 936-940.

Nicolaï B.M., Beullens K., Bobelyn E., Peirs A., Saeys W., Theron K.I., Lammertyn J. 2007. Nondestructive measurement of fruit and vegetable quality by means of NIR spectroscopy: A review. Postharvest Biol. Tech., 46: 99-118.

Nogales-Bueno J., Hernández-Hierro J.M., Rodríguez-Pulido F.J., Heredia F. . 2014. Determination of technological maturity of grapes and total phenolic compounds of grape skins in red and white cultivars during ripening by near infrared hyperspectral image: A preliminary approach. Food Chem., 152: 586-591. 
Pu Y.-Y., Feng Y.-Z., Sun D.-W. 2015. Recent progress of hyperspectral imaging on quality and safety inspection of fruits and vegetables: A Review. Compr. Rev. Food Sci. Food Safety, 14: $176-188$.

Quilitzsch R., Baranska M., Schulz H., Hoberg E. 2005. Fast determination of carrot quality by spectroscopy methods in the UV-VIS, NIR and IR range. J. Appl. Bot. Food Qual., 79: 163.

Rajkumar P., Wang N., Eimasry G., Raghavan G.S.V., Gariepy Y. 2012. Studies on banana fruit quality and maturity stages using hyperspectral imaging. J. Food Engin., 108: 194-200.

Sasson A., Monselise S.P. 1977. Electrical conductivity of 'Shamouti' orange peel during fruit growth and postharvest senescence. J. Amer. SOC. Hort. Sci., 102: 142-144.

Schulz H., Quilitzsch R., Drews H.H., Kruger H. 2000. Estimation of minor components in caraway, fennel and carrots by NIRS-comparison of results from dispersive and fourier-transform instruments. Int. Agroph., 14: 249-254.

Shao Y., He Y., Gómez A.H., Pereir A.G., Qiu Z., Zhang Y. 2007. Visible/near infrared spectrometric technique for nondestructive assessment of tomato 'Heatwave' (Lycopersicum esculentum) quality characteristics. J. Food Engin., 81: 672-678.

Ulrich D., Nothnagel T., Dunemann F. 2012. Assessment of aroma quality by holistic analysis methods. Acta Hortic., 944: 23-27.

Vaiphasa C., Ongsomwang S., Vaiphasa T., Skidmore A.K. 2005. Tropical mangrove species discrimination using hyperspectral data: A laboratory study. Estuarine, Coastal Shelf Sci., 65: 371-379.

VAn Der Meer F. 2004. Analysis of spectral absorption features in hyperspectral imagery. Int. J. Appl. Earth Obs. Geoinf., 5: 55-68.

Williams P., Manley M., Fox G., Geladi P. 2010. Indirect detection of Fusarium verticillioides in maize (Zea maize L.) kernels by NIR hyperspectral imaging. J. Near Infrared Spectrosc., 18: 49-58.

Winsor G., Adams P. 1987. Diagnosis of mineral disorders in plants. In: Glasshouse crops. Robinson J.B.D. (Ed.), Vol. 3. Crown, London, 166 pp.

Wold S., Esbensen K., Geladi P. 1987. Principal component analysis. Chemom. Intell. Lab. Syst., 2: 37-52.

Wu D., He Y., Nie P., Cao F., Bao Y. Wu D., He Y., Nie P., Cao F., Bao Y.2010. Advanced applications of hyperspectral imaging technology for food quality and safety analysis and assessment: A review. Part I. Fundamentals. Innov. Food Sci. Emerg., 19: 1-14.

Wu D., Sun D.-W. 2013. Advanced applications of hyperspectral imaging technology for food quality and safety analysis and assessment: A review. Part I. Fundamentals. Innov. Food Sci. Emerg., 19: 1-14.

Zhao J., Ouyang Q., Chen Q., Wang J. 2010. Detection of bruise on pear by hyperspectral imaging sensor with different classification algorithms. Sensor Letters, 8: 570-576.

Zhao J., Vittayapadung S., Quansheng C., Chaitep S., Chuaviroj R. 2009. Nondestructive measurement of sugar content of apple using hyperspectral imaging technique. Maejo Int. J. Sci. Tech., 3: 130-142.

Zude M., Birlouez-Aragon I., Paschold P.-J., Rutledge D.N. 2007. Non-invasive spectrophotometric sensing of carrot quality from harvest to consumption. Postharvest Biol. Technol., 45: $30-37$. 